Çukurova Üniversitesi Mühendislik Fakültesi Dergisi, 36(4), ss. 941-954, Aralık 2021

Cukurova University Journal of the Faculty of Engineering, 36(4), pp. 941-954, December 2021

\title{
Effect of Various Matrix Materials on Mechanical Properties of Basalt/Jute/Glass Fiber Reinforced Hybrid Composites
}

\author{
Berkay KARAÇOR ${ }^{* 1}$ ORCID 0000-0001-5208-366X \\ Mustafa ÖZCANLI ${ }^{1}$ ORCID 0000-0001-6088-2912
}

${ }^{1}$ Cukurova University, Faculty of Engineering, Department of Automotive Engineering, Adana

Geliş tarihi: 09.07.2021 Kabul tarihi: 10.12.2021

Attf şekli/ How to cite: KARAÇOR, B., ÖZCANLI, M., (2021). Effect of Various Matrix Materials on Mechanical Properties of Basalt/Jute/Glass Fiber Reinforced Hybrid Composites. Çukurova Üniversitesi, Mühendislik Fakültesi Dergisi, 36(4), 941-954.

\begin{abstract}
In this research, the effect of different matrix materials (epoxy and vinylester) on the mechanical properties of Basalt, Jute, and Glass fiber-based hybrid composites were analyzed mechanically and morphologically. The mechanical test results were achieved by the Tensile test and Vickers hardness test, while morphologic images were obtained by Scanning Electron Microscopy. Basalt fiber fabric, Jute fiber fabric, and Glass fiber fabrics of $86 \mathrm{gr} / \mathrm{m}^{2}$ and $100 \mathrm{gr} / \mathrm{m}^{2}$ were used as reinforcement elements, while epoxy and vinylester were utilized as matrix materials. A vacuum assisted resin transfer molding method was used as the production technique. In the results, it is given how the use of different reinforcement element types and different matrix materials affects the mechanical properties of the produced composite samples. Results show that the tensile strength of basalt fiber/glass fiber $\left(100 \mathrm{gr} / \mathrm{m}^{2}\right)$ reinforced with epoxy is the highest in all of the produced composites. In terms of microhardness, the hardness value of basalt fiber/glass fiber $\left(100 \mathrm{gr} / \mathrm{m}^{2}\right)$ reinforced epoxy composites have 1.39 times higher than basalt/glass fiber $\left(100 \mathrm{gr} / \mathrm{m}^{2}\right)$ reinforced vinylester composites. Scanning electron microscopy (SEM) analysis was utilized to examine the fiber rupture and fracture mode in hybrid composites. As a result of the analysis, also it was observed SEM results support the mechanical test results.
\end{abstract}

Key Words: Matrix material, Glass fiber, Basalt fiber, Jute fiber, Mechanical properties

\section{Çeşitli Matris Malzemelerinin Bazalt/Jüt/Cam Elyaf Takviyeli Hibrit Kompozitlerin Mekanik Özelliklerine Etkisi}

$\ddot{\mathbf{O} z}$

$\mathrm{Bu}$ araştırmada, farklı matris malzemelerinin (epoksi ve vinilester) Bazalt, Jüt ve Cam elyaf esaslı hibrit kompozitlerin mekanik özellikleri üzerindeki etkisi mekanik ve morfolojik olarak analiz edilmiştir. Çekme testi ve Vickers sertlik testi ile mekanik test sonuçları elde edilirken, Taramalı Elektron Mikroskobu ile morfolojik görüntüler elde edildi. Takviye elemanı olarak bazalt elyaf kumaş, Jüt elyaf kumaş ve $86 \mathrm{gr} / \mathrm{m}^{2}$ ve $100 \mathrm{gr} / \mathrm{m}^{2}$ cam elyaf kumaşlar, matris malzemesi olarak epoksi ve vinylester kullanılmıştır. Üretim tekniği olarak vakum destekli reçine transfer kalıplama yöntemi kullanılmıştır.

*Sorumlu yazar (Corresponding author): Berkay KARAÇOR, bkaracor@cu.edu.tr 
Effect of Various Matrix Materials on Mech. Prop. of Basalt/Jute/Glass fiber Reinf. Hybrid Comp.

Sonuçlarda, farklı takviye elemanı tipleri ve farklı matris malzemelerinin kullanılmasının üretilen kompozit numunelerin mekanik özelliklerini nasıl etkilediği verilmiştir. Sonuçlar, epoksi ile güçlendirilmiş bazalt elyaf/cam elyafın $\left(100 \mathrm{gr} / \mathrm{m}^{2}\right)$ çekme mukavemetinin üretilen tüm kompozitler içinde en yüksek olduğunu göstermektedir. Mikrosertlik açısından bazalt elyaf $/ \mathrm{cam}$ elyaf $\left(100 \mathrm{gr} / \mathrm{m}^{2}\right)$ takviyeli epoksi kompozitlerin sertlik değeri, bazalt/cam elyaf $\left(100 \mathrm{gr} / \mathrm{m}^{2}\right)$ takviyeli vinylester kompozitlere göre 1,39 kat daha yüksektir. Hibrit kompozitlerde fiber kopma ve kırılma modunu incelemek için taramalı elektron mikroskobu (SEM) analizi kullanılmıştır. Analiz sonucunda SEM sonuçlarının da mekanik test sonuçlarını desteklediği görülmüştür.

Anahtar Kelimeler: Matriks malzeme, Cam fiber, Bazalt fiber, Jüt fiber, Mekanik özellikler

\section{INTRODUCTION}

Composite materials, with their different mechanical, physical, and chemical properties, are among the materials whose use has recently increased in advanced technology applications in the fields of automotive, aerospace, construction, medicine, and in many engineering fields [1]. In modern advanced composite materials, with the effect of the plastic age, fiber-reinforced varieties have become one of the most important types in terms of structure [1]. Natural fibers are examined in three categories, depending on the source, as animal, plant and mineral-based fibers. Examples of common plant fibers encompass jute fibers, flax fibers, banana fibers, bamboo fibers, sisal fibers, kenaf fibers and coconut fibers, while animalbased fibers contain wool from alpaca and chicken feathers and silk from butterfly larvae and spiders. Basalt fiber, which has lately achieved favor as composite reinforcement, is one of the best-known mineral fibers [2]. This mineral type fiber is extruded from molten basalt rock, usually in diameters between $13 \mu \mathrm{m}$ and $20 \mu \mathrm{m}$. It is known to be a versatile material and to operate in temperature ranges from $-200{ }^{\circ} \mathrm{C}$ to $+600{ }^{\circ} \mathrm{C}$ [3-6]. The importance of basalt fibers is increasing gradually as an alternative to glass fibers in reinforcement elements in composite materials in terms of ecological reliability, natural longevity, and non-flammability. Besides, basalt fiber composites are preferred over glass fibers in the automotive industry where acids are used extensively, as they are superior to the acid, alkali, and vapor resistance properties of glass fibers with their high chemical stability [3-6]. They are also ideal materials for thermal and sound insulation of automobile interior and engine parts. Owing to its superior combination of wear and heat resistance in brake systems in vehicles, it has also replaced asbestos [3-6]. Basalt fibers are materials that have been used extensively in military applications since their discovery and have the potential to combine with other fibers for lightweight structures with affordable cost and good mechanical properties. Basalt fiber is referred to as lower priced and more environmentally friendly compared to carbon fibers, with both the absence of resource problems and the originality of the production process, as it is obtained from basaltic volcanic rocks. While basalt fiber is used to reinforce thermoset polymers such as epoxy and polyester, it shows good adherence with various polymer matrices [7-8]. With its various properties, basalt fibers are used in many areas as friction and wear materials in automobiles, corrosion resistance material in the chemical industry, and reinforcement material in the construction sector. It is widely used in automotive, especially in the production of car headliners and high temperature insulation of automobile catalysts [9]. Jute, linen, wood, cotton, bamboo, sisal and hemp from natural fibers are used as reinforcements in polymeric matrices. When all naturally obtained reinforcement materials are examined, the availability of jute fabrics in desired shapes and being cost effective compared to others is an important potential for future studies. Jute is made of vegetable fibers and consists of cellulose units; its fibers are biodegradable and recyclable. Among the natural vegetable fibers, jute has relatively high tensile strength and high production volume as well as being an environmentally friendly material, showing good thermal and acoustic insulation 
properties. However, the cellulose structure of jute fibers is rich in hydroxyl groups and its compatibility with polymeric matrices is not strong. This disadvantageous situation is eliminated by applying chemical or physical modifications to the fiber surfaces, thereby improving the interfacial bond of jute fibers with polymeric materials [10-12]. Glass fibers are one of the materials that have many applications in various industrial sectors such as thermal and electrical insulation, various sports equipment, household goods. The properties of glass fiber reinforced products such as the expected strength in structural applications in automobiles and at the regard of well interfacial matrix-fiber bond and improved production methods have proven the use of glass fibers in automotive structural parts. In terms of production costs, the cost of glass fibers is lower than carbon fibers. Moreover, the fact that glass fiber is a strong and hard material would provide a significant benefit in the cost and strength of hybrid materials in hybridization processes. It has been observed that hybrid laminates made with glass/plant fiber are at the forefront of features such as producing sustainable materials, causing the least damage to the environment during production and at the end of their service life, having sufficient mechanical resistance and an acceptable impact performance [13-15]. In the literature, there are some studies on the effect of different glass fibers on the mechanical properties of hybrid composite samples created with jute and basalt. There are only a few studies in the literature that have worked on hybrid composites made using glass fibers of different weights per square meter, and basalt, jute, and glass fiber reinforced composites created using epoxy and vinylester resin. Sarasini et al. [16] studied the effect of stacking sequence on low-speed impact, bending, and acoustic properties of epoxy composites hybridized using basalt fibers and glass fibers. They utilized two different stacking orders, intercalated and sandwich-like. Flexural test results show that glass fiber hybrid laminates have the highest flexural strength, whereas basalt fiber laminates have the lowest. Because of the stacking order, it has emerged that the samples which were hybridized with basalt and glass fiber intercalated hybrid laminates provide higher strength in comparison to sandwich configuration. Gangappa and Kulkarni [17] hybridized with polyester resin using basalt and jute as reinforcement material. They examined the effect of warp and weft direction and material thickness on tensile and compressive strength. It was understood that warp weaves valued both tensile and compression strength higher than weft weaves. It has been observed that the increase in material thickness has a decreasing effect on tensile strength and an increase in compression strength values. Jusoh et al. [18] investigated how the hybridization process and the pattern of these fibers in composites formed with glass fiber, basalt, jute, and flax fibers affect the bending strength. In terms of hybridization, it was understood that the glass/jute sandwich-like structure showed optimum integration with E-glass against other fibers produced in the research, and the delamination mechanism did not occur due to the presence of the glass layer in the fracture analysis. Dhiman and Sharma [19] manufactured jute and walnut shell filled jute/basalt hybrid composites in different proportions and examined their mechanical performance. The results show that the addition of walnut shell filler (between $0 \%$ and $15 \%$ ) increases the tensile strength of basalt/jute fiber composites by about $60 \%$. Kishore et al. [20] analyzed tribological properties in samples made with basalt, jute, and jute/basalt hybrid composite materials using graphene as filling material. The specific wear rate and friction coefficient were discovered to be the lowest with the hybrid composite including $0.4 \%$ graphene by weight. It was stated that the basalt fiber on the contact surface provided a $53 \%$ improvement in the friction coefficient and specific wear rate. In another study using jute/basalt reinforced hybrid composites, Kishore et al. [21] used graphene in three different amounts $(0.2 \%, 0.4 \%$ and $0.6 \%)$ as a filler. It was observed that hybrid composites with graphene-doped composites showed fewer roughness values than composite without graphene added. Fiore et al. [22] studied the effect of aging on mechanical properties by producing jute and jute/basalt hybrid composites with vacuum infusion technique. The results of quasi static bending tests and low velocity impact tests showed that basalt fibers increased the durability of natural 
Effect of Various Matrix Materials on Mech. Prop. of Basalt/Jute/Glass fiber Reinf. Hybrid Comp.

fiber composites and jute/basalt hybrid laminates gave the best mechanical results. Surface treatment applications are applied to increase the durability effect of the fibers in composites made with natural fibers and to exhibit a better interface bond with the matrix [23]. Raajeskrishna et al. [24] studied the strength of tensile and stiffness of hybrid composites with and without surface treatment, reinforced with glass fiber fabric and basalt fabric with sandwich stacking sequence configuration. They also confirmed their experimental results with finite element analysis. The fibers of the basalt fabric in the inner structure and the glass fabric as the outer surface, treated with $\mathrm{HCl}$ (hydrochloric acid), have the highest tensile strength with $356.39 \mathrm{MPa}$, shows the positive effect of the hybridization process and surface treatment on the tensile strength. Fiore et al. [25] surveyed the mechanical properties, morphological properties and aging resistance of jute and basalt reinforced bio-based epoxy composites. They used jute and basalt fibers in three different stacking sequences, and in the analysis, interply hybrid composites reached better values compared to jute lamina fiber composites and turned out to be an important alternative for outdoor applications. Sanchez-Galvez et al. [26] studied the effect of different environmental conditions on the high-speed impact performance of basalt, glass/basalt, and carbon/basalt hybrid composites. While the best performance was observed for glass/basalt hybrid reinforcement with a ballistic limit of $480 \mathrm{~m} / \mathrm{s}$, experimental results were also confirmed by analytical results. Jusoh et al. [27] analyzed the impact of shifting the piling order of fabric layers on the low-speed impact behavior of hybrid composites containing glass woven fabric, basalt fabric, jute fabric, and linen woven fabric in varying sequences within the epoxy matrix. When the hybrid composite values are examined, the results of the specific energy absorption and indentation energy analysis are mainly dependent on the high modulus and strength value of the glass fiber rather than the low features of the natural fibers. Esnaola [28] studied the energy absorption ability of products created by hybridizing glass fiber and basalt fiber with polyester. The results obtained showed that among the six different configurations and fiber strands used, the hybrid configuration where polyester was used with E-glass and basalt fibers avoided unstable collapse problems compared to basalt/polyester hybrids. The object of this search is to examine the main effects of using different matrixes on the mechanical properties of hybrid composites made of glass fiber fabric and jute fabric with basalt fiber from mineral fibers and to make the morphological analysis of the products obtained.

\section{MATERIAL AND METHODS}

\subsection{Material}

Basalt, E-glass and Jute plain weave fabrics were used as reinforcement materials. All reinforcement materials were supplied by Kompozitshop, Turkey. Table 1 gives the fabric parameters of this study. The fabric samples are indicated in Figure 1.

Table 1. Properties of fabrics

\begin{tabular}{|c|c|c|c|c|}
\hline Fabric & $\begin{array}{c}\text { Weight } \\
\left(\mathbf{g r} / \mathbf{m}^{\mathbf{2}}\right)\end{array}$ & $\begin{array}{c}\text { Thickness } \\
\text { of fabric } \\
(\mathbf{m m})\end{array}$ & $\begin{array}{c}\text { Warp } \\
\mathbf{( t e x )}\end{array}$ & $\begin{array}{c}\text { Weft } \\
\mathbf{( t e x )}\end{array}$ \\
\hline Basalt & 280 & 0.2 & - & - \\
\hline Jute & 265 & 0.7 & 312.5 & 312.5 \\
\hline Glass Fiber & 86 & 0.06 & $34 \times 1$ & $12 \times 12.5$ \\
\hline Glass Fiber & 100 & 0.08 & $22 \times 1$ & $24 \times 2.8$ \\
\hline
\end{tabular}

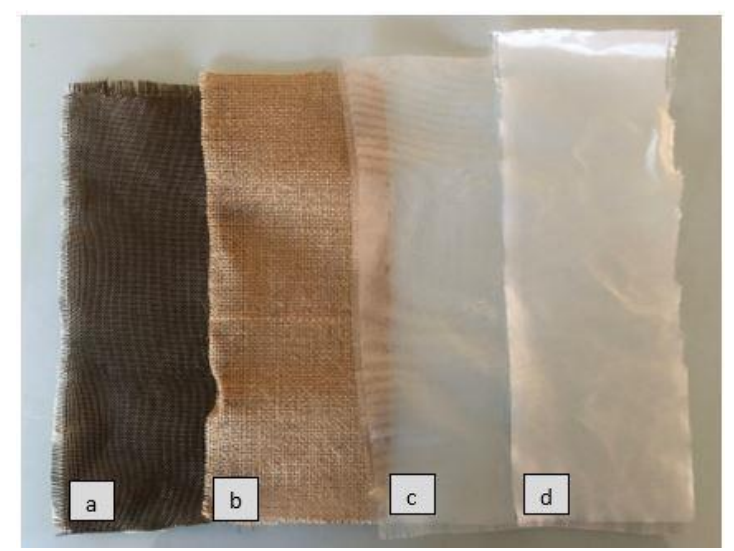

Figure 1. Fabric samples a) Basalt fiber fabric b) Jute fiber fabric c) Glass fiber fabric $\left(86 \mathrm{gr} / \mathrm{m}^{2}\right)$ d) Glass fiber fabric $\left(100 \mathrm{gr} / \mathrm{m}^{2}\right)$ 
Epoxy resin (L160) with its related hardener (LH160) and vinyl ester with its additives was used as a matrix material. Table 2 and Table 3 indicates the technical properties of the resin systems. While the mixing ratio of epoxy resin and hardener is $100: 25 \pm 2$ by weight as specified by the manufacturer, the mixing ratio for vinyl ester resin is Vinyl ester: cobalt: perox ratio of 1: 0.0004: 0.02 weight.

Table 2. Epoxy and hardener properties

\begin{tabular}{|l|c|c|}
\hline & L160 Infusion epoxy & LH160 Hardener \\
\hline Operating temperature $\left({ }^{\circ} \mathrm{C}\right)$ & $\begin{array}{r}-60 /+50 \text { without heat treatment } \\
-60 /+80 \text { by applying heat treatment }\end{array}$ \\
\hline Process temperature $\left({ }^{\circ} \mathrm{C}\right)$ & $+10 /+50$ & - \\
\hline Density $\left(\mathrm{g} / \mathrm{cm}^{3}\right)$ & $1.13-1.17$ & $0.96-1.0$ \\
\hline Viscosity $(\mathrm{mPas})$ & $700-900$ & $10-50$ \\
\hline Refractor index & $1.5480-1.5530$ & $550-650$ \\
\hline $\begin{array}{l}\text { Amine value } \\
(\text { mgr KOH/gr) }\end{array}$ & - & $25^{\circ} \mathrm{C}$ \\
\hline Measurement Conditions & $25^{\circ} \mathrm{C}$ & -1.5210 \\
\hline
\end{tabular}

Table 3. Vinylester properties

\begin{tabular}{|l|c|c|}
\hline & Molding & Laminate \\
\hline Heat distortion temperature $\left({ }^{\circ} \mathrm{C}\right)$ & 137 & 132 \\
\hline Flexural strength $(\mathrm{MPa})$ & $130-140$ & 7400 \\
\hline Bending coefficient $(\mathrm{MPa})$ & $3400-4000$ & \multicolumn{2}{|c|}{93} \\
\hline Viscosity (mPas) & \multicolumn{2}{|c|}{$180-220$} \\
\hline Tensile strength $(\mathrm{MPa})$ & 42 & 50 \\
\hline Barcol Hardness & & \multicolumn{2}{|c|}{} \\
\hline
\end{tabular}

In this study, twelve composite samples using a different matrix and having various fabric stacking sequences were produced. Reference codes for fabric layers in composite samples are given in Table 4.

Table 4. Codes of produced samples

\begin{tabular}{|l|l|}
\hline Composite codes & Fabric types \\
\hline B & Basalt fabric \\
\hline J & Jute fabric \\
\hline G86 & Glass Fiber fabric $\left(86 \mathrm{gr} / \mathrm{m}^{2}\right)$ \\
\hline G100 & Glass Fiber fabric $\left(100 \mathrm{gr} / \mathrm{m}^{2}\right)$ \\
\hline JB & Jute/Basalt Fiber hybrid composite \\
\hline BG86 & Basalt/Glass Fiber $\left(86 \mathrm{gr} / \mathrm{m}^{2}\right)$ hybrid composite \\
\hline BG100 & Basalt/Glass Fiber $\left(100 \mathrm{gr} / \mathrm{m}^{2}\right)$ hybrid composite \\
\hline
\end{tabular}


Effect of Various Matrix Materials on Mech. Prop. of Basalt/Jute/Glass fiber Reinf. Hybrid Comp.

After $60{ }^{\circ} \mathrm{C}$ curings at 1 hour, the composite specimens were cut by the water jet machine to the test dimensions specified in the standards.

\subsection{Method}

In order to produce jute, basalt, and glass fiber fabric reinforced composite laminates, vacuum assisted resin transfer molding was used. In this method, a vacuum force is used to remove air from the reinforcement material and allow the resin to enter the preform. After making provision the designated area by applying a release agent, the fabrics were laid on the table and the layered fabric was covered with peel ply, an infusion mesh, and a vacuum bag. Sealing in the system was ensured by sticking the vacuum sealing band around the fabrics. A small hollow was also made in the vacuum bag to allow the inlet and outlet pipes to cross through. Then, in order to the suck the resin, vacuum pump was turned on. The vacuum pump was operated for about 2 hours (about 1 bar) and was turned off when the excess resin flow stops. The whole process was carried out at room temperature $\left(20{ }^{\circ} \mathrm{C} \pm 2{ }^{\circ} \mathrm{C}\right)$ under 1 bar pressure and the sample formed was left to cure for 24 hours.

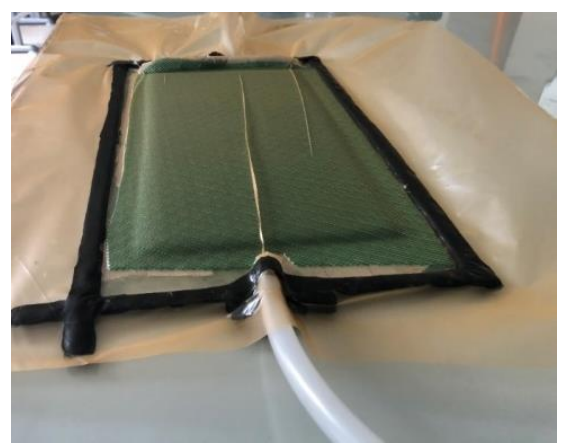

Figure 2. Vacuum assisted resin transfer molding process

\subsubsection{Testing}

\subsubsection{Mechanical Testing}

In this research, the mechanical properties were interpreted in terms of the tensile strength of the produced composite samples. The tensile test was done with reference to the ASTM D 3039 standard using ALŞA Hydraulic Test Machine (KOLUMAN Automotive Industry Laboratory) and $2 \mathrm{~mm} / \mathrm{min}$ is set as the cross-head speed on the device with a $98000 \mathrm{kN}$ load cell [29]. Beforehand the test, the width and depth of the consecutive test samples were measured and the values were processed into the machine. Figure 3 indicates the universal tensile testing machine. By the tensile test; Tensile Strength, Elastic Modulus, StressStrain diagram, and Elongation rate of hybrid composites were calculated. After the five samples were cut in the water jet in each configuration created, the tests were performed and the arithmetic averages of these 5 sample values were taken and indicated in the results.

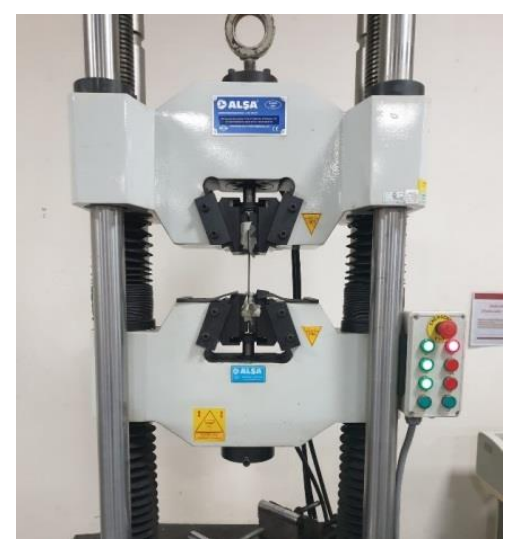

Figure 3. Tensile testing machine

\subsubsection{Hardness Test}

Vickers hardness test, also called the 136-degree diamond pyramid hardness test, is a micro indentation test method used for materials. The Vickers hardness number of the material is determined by creating a square indentation, the diagonals of which are measured, in the indentation on the material. This value is obtained directly from the Vickers hardness testing machine [30]. Vickers hardness value was found by taking an average of fifteen readings in different places in each sample. AOB Lab product machine was used to analyze the hardness test of samples according to the ASTM E92-17 standard [31]. The Vickers hardness test machine is shown in Figure 7. 


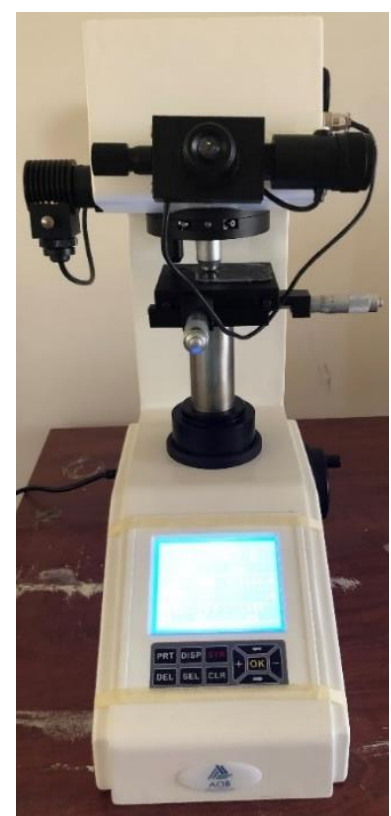

\subsubsection{Morphological Analysis}

Scanning electron microscopy (SEM) method is used to analyze the fiber morphology of the materials and in this way, the fracture surface and fiber-matrix interactions of the composites are examined. The samples produced were observed using the Scanning Electron Microscope (SEM) FEI Quanta 650 Field Emission device at 100V$30 \mathrm{kV}$ acceleration voltage. The magnification capacity of the device is in the range of 6$1.000 .000 \mathrm{x}$ times (Figure 5). The non-conductive surfaces in the composites were overlaid with gold with the help of the Q150R ES spray coating device before being subjected to SEM. Generally, a conductive gold layer was fixed to the metal sample holder by surface evaporation by means of an electrically conductive adhesive to prevent electrostatic charging in the samples. Figure 6 shows the device used for the gold plating process.

Figure 4. Hardness test machine

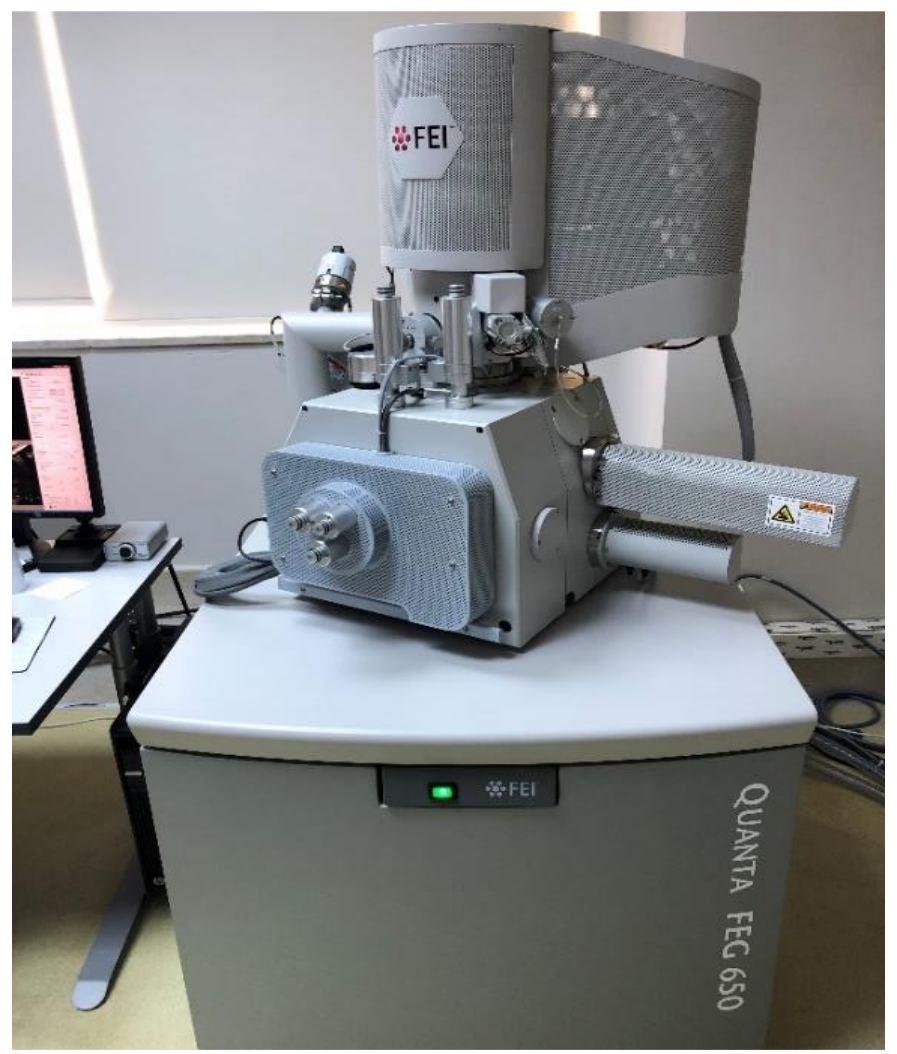

Figure 5. SEM Analysis machine 


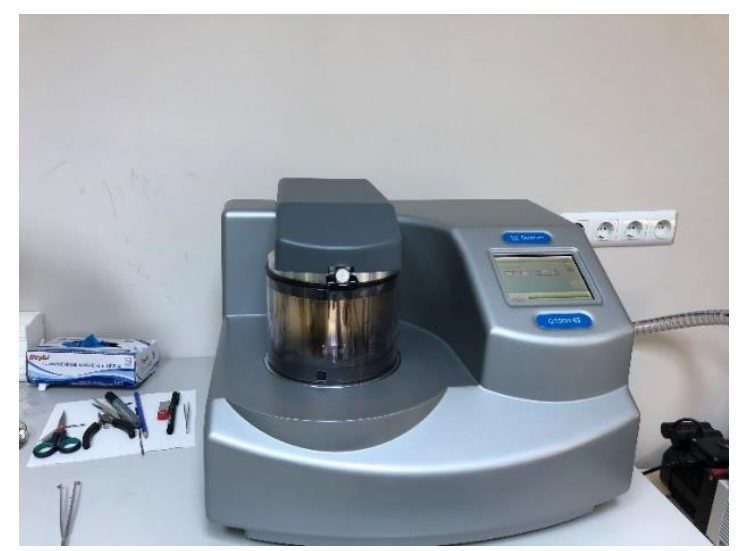

Figure 6. Gold plating process machine

\section{RESULTS AND DISCUSSIONS}

\subsection{Mechanical Testing Analysis Results}

Tensile test results are indicated in Figure 7, Figure 8, and Figure 9. As shown in Figure 7, the tensile strength value of JB with epoxy resin is $11.17 \%$ higher than JB with vinylester resin. BG100 tensile strength value is the highest in samples prepared with both epoxy and vinylester resin. The difference between BG86 and BG100 tensile behavior is $1.6 \%$ for vinylester reinforced composite and $0.5 \%$ for epoxy reinforced composite samples. The results indicate that the use of epoxy resin instead of vinylester in basalt reinforced composite matrices increases the tensile strength. In one of the searches about diverse resin usage [32], it is stated that the use of epoxy resin in the composite structure formed by using vinylester and epoxy resin with basalt fiber corresponds to a $29 \%$ increase in tensile strength. In another work [17], tensile strength values of $153.87 \mathrm{MPa}$ and 106.902 $\mathrm{MPa}$ in the warp direction were obtained in the structure prepared in two different thicknesses, using Basalt and Jute fabrics as reinforcement elements and vinylester resin as matrix element. Considering, BG86 samples, the tensile strength of the samples made with epoxy resin increased by $12.46 \%$ compared to composites with vinylester resin. This increase was not seen only in JB samples, which is thought to be due to sequencing order.

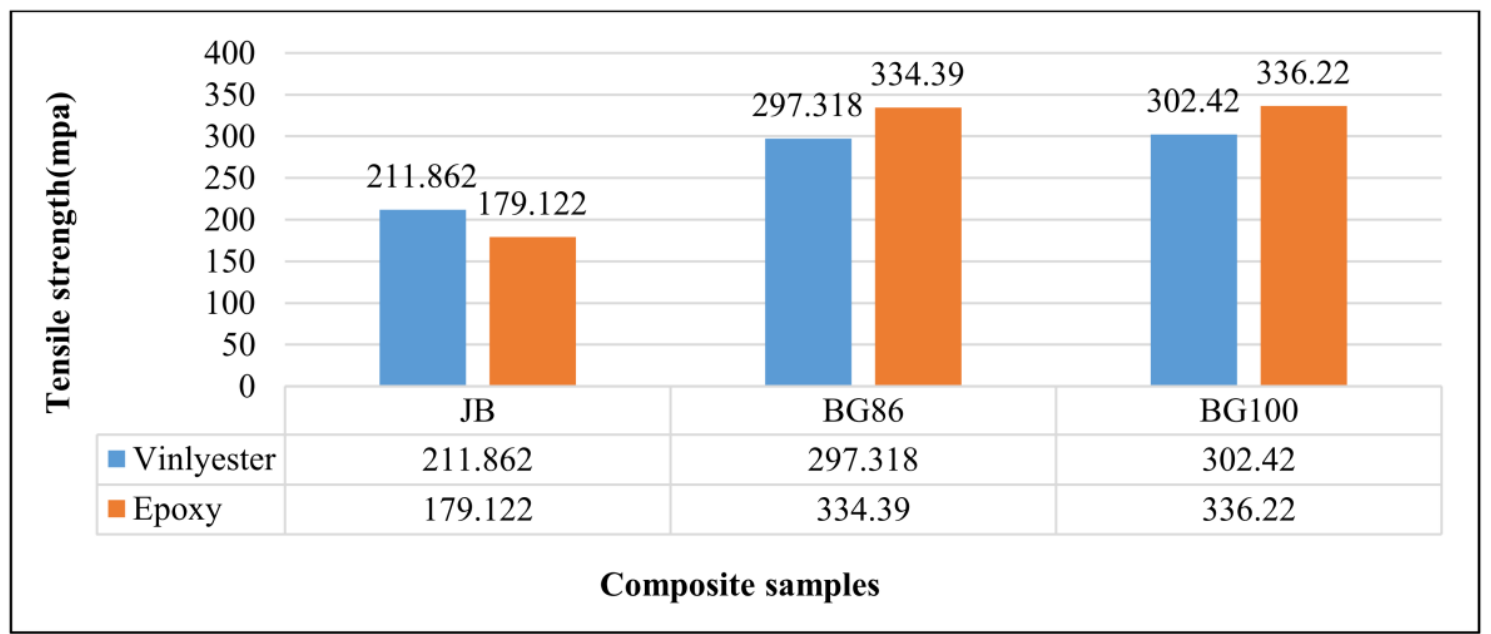

Figure 7. Tensile strength of produced samples 
Figure 8 indicates the elastic modulus of produced composite samples. For instance, the difference of elastic modulus of BG100 epoxy and vinylester samples only $6.52 \%$. This indicates that although two different resins are used in the linear region, a similar slope is observed, the curves diverge while increasing the applied load and present different tendencies. A similar trend is acceptable for BG86 epoxy and vinylester resin samples with a $12.8 \%$ difference in elastic modulus. It is stated that this difference is due to the chemical structure of vinylester and epoxy resins, and that resin-fiber compatibility is better between epoxy and fabrics. In one of the researches about varied resin usage [32], the use of epoxy resin caused a $13.6 \%$ increase in elastic modulus compared to the use of vinylester resin.

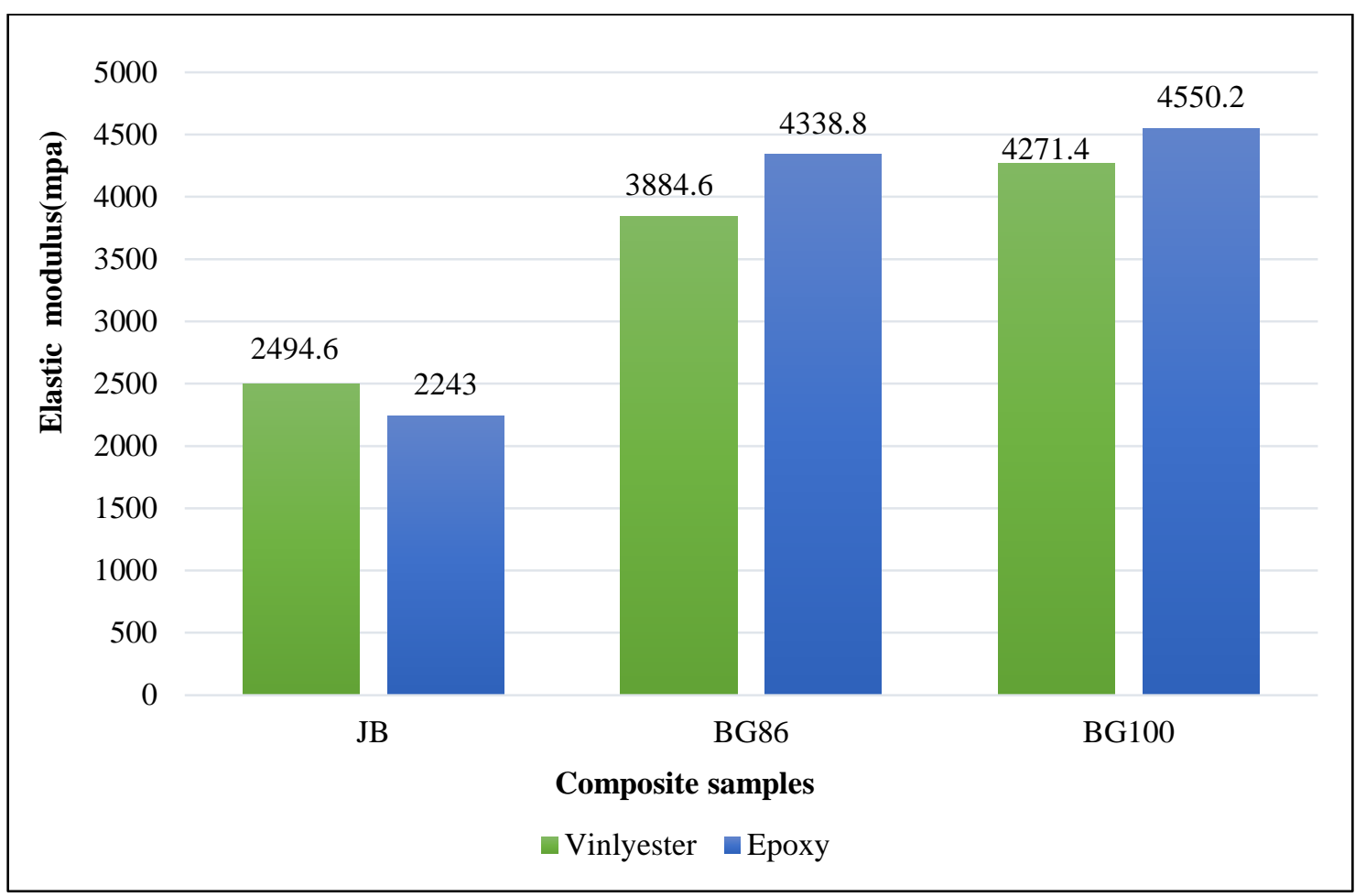

Figure 8. Elastic modulus of composite samples

Figure 9 indicates elongation at the break of samples. Elongation at break is defined as the ratio between the changing length of the material after fracture and the initial length of the material. From the results,

BG100 vinylester composite sample has the lowest elongation at break among vinylester composite samples. Since BG100 sample has the highest tensile strength value, the amount of elongation has taken the lowest value in parallel with this.

JB epoxy composite sample has the lowest elongation value among the epoxy composite samples. Since JB sample showed high compatibility with epoxy resin, and the elongation values were not high.

Because, one of the advantages of using epoxy resin is that it indicates low shrinkage during the curing process, with less than 5\% shrinkage detected in epoxy resins, while up to $12 \%$ in volume reduction was found in vinyl ester resins [9]. This provides better mechanical properties in structures using epoxy resin. 


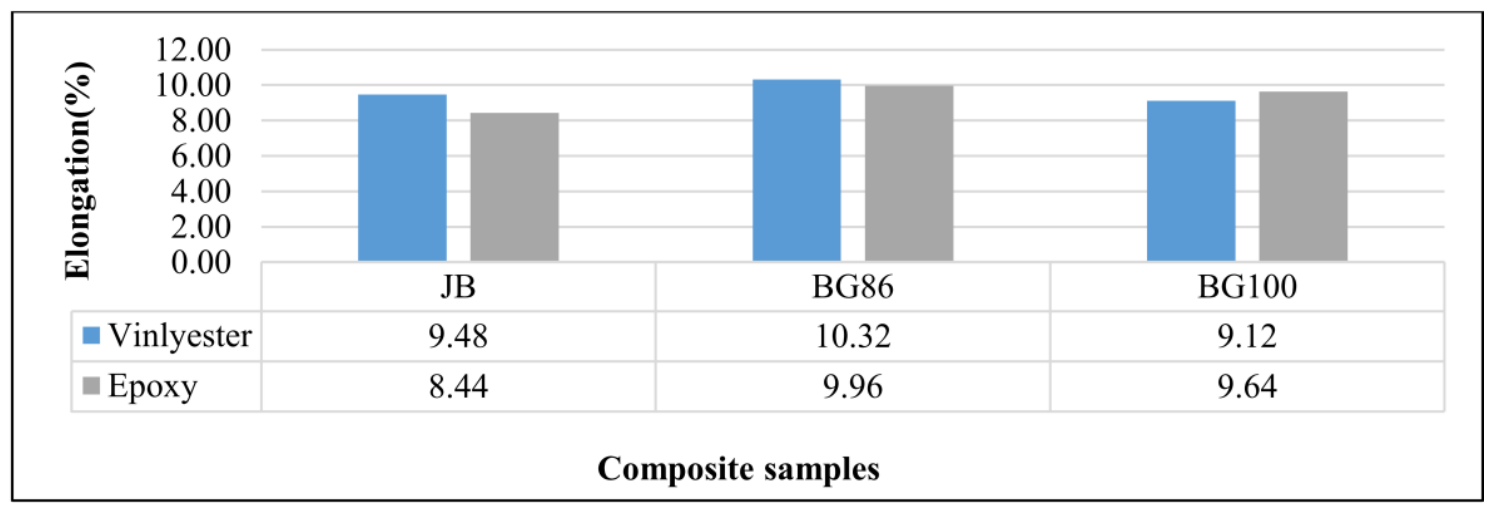

Figure 9. Elongation of composite samples

\subsection{Hardness Test Analysis Results}

According to Vickers Hardness test results, produced composite samples with epoxy resin have higher hardness values than produced samples with vinylester resin. When the results of the JB sample are investigated, the hardness value produced with epoxy resin is $80.7 \%$ higher than the sample produced with vinylester resin. In the results of BG86 and BG100, the hardness value of samples using the epoxy resin is $64 \%$ and $39.9 \%$ higher than with samples using the vinylester resin, respectively.

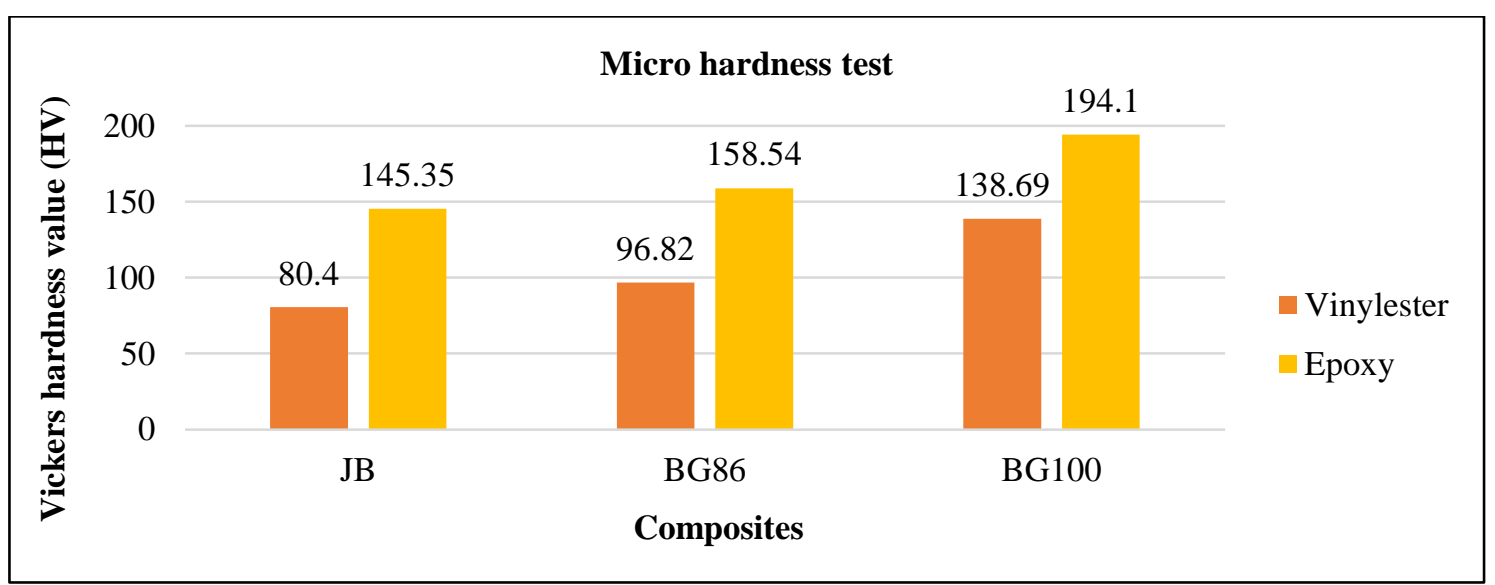

Figure 10. Vickers hardness test results

By the time the fiber fabrics used were viewed, it was understood that the hardness value of the samples made with $86 \mathrm{gr} / \mathrm{m}^{2}$ glass fiber fabric and vinylester resin of the basalt fiber fabric was approximately 1.2 times higher than the hybrid composite sample made by the basalt fiber fabric with jute fiber fabric. The hardness value of the BG100 sample was found to be 1.43 times higher than the BG86 sample as a result of the comparison of the hardness value of the basalt fiber fabric in hybrid composites produced with 86 $\mathrm{gr} / \mathrm{m}^{2}$ and $100 \mathrm{gr} / \mathrm{m}^{2}$ glass fiber fabrics using vinylester resin. The difference between these BG86 and BG100 is associated with the fact that the mesh structure of the $100 \mathrm{gr} / \mathrm{m}^{2}$ fabrics is more dense and stronger than the $86 \mathrm{gr} / \mathrm{m}^{2}$ woven fabrics. The higher hardness value of the samples made with epoxy resin than the samples made with vinylester resin can be attributed to the better bonding of the chemical bonds of epoxy with fiber 
fabrics. The long chain molecules and polar groups in epoxy resin provide a stronger bond than the structure in vinylester resin. In the Shore hardness test performed in another study, the hardness value of the sample with the BGB (Basalt-Glass-Basalt) order was $36.6 \%$ higher than the hardness value of the sample in the GBG (Glass-Basalt-Glass) order. The difference in this hardness is due to the hardness of basalt rocks [24].

\subsection{SEM Analysis Results}

Figures $11 \mathrm{a}-\mathrm{f}$ shows the morphological structure of the produced composites after the tensile test. In samples with more voids appearing on the surface as shown in Figure 11a-c, vinylester resin is the matrix element. It is understood from the images that the use of glass fiber instead of jute fiber strengthens the structure even more. As seen in
Figure 11d-f, less voids and more fiber breakage occurred in the composite samples produced with epoxy resin. This can be attributed to the improved tensile properties of BG100 produced with epoxy resin over other composites. In Figure $11 \mathrm{e}-\mathrm{f}$ for BG86 and BG100 samples, minimal matrix cracking and less fiber splitting resulted in higher tensile absorption while also giving the samples high tensile strength values.

Because of the susceptible nature of the jute fiber, it is seen that there is some fiber breakage and a sharp cut in places due to the load on the surface of JB composites. The semi-brittle nature of the glass fiber and the fiber delamination and separation when the load is applied bring basalt fibers to the fore because they can withstand high tensile loads [13].

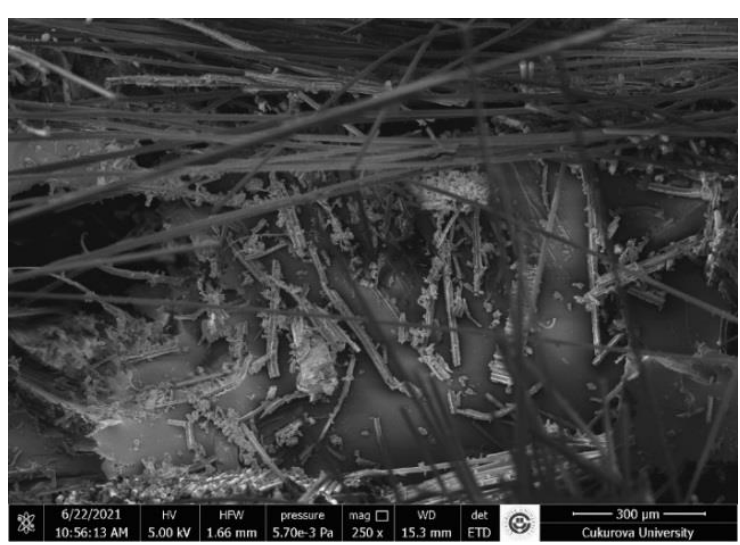

(a)

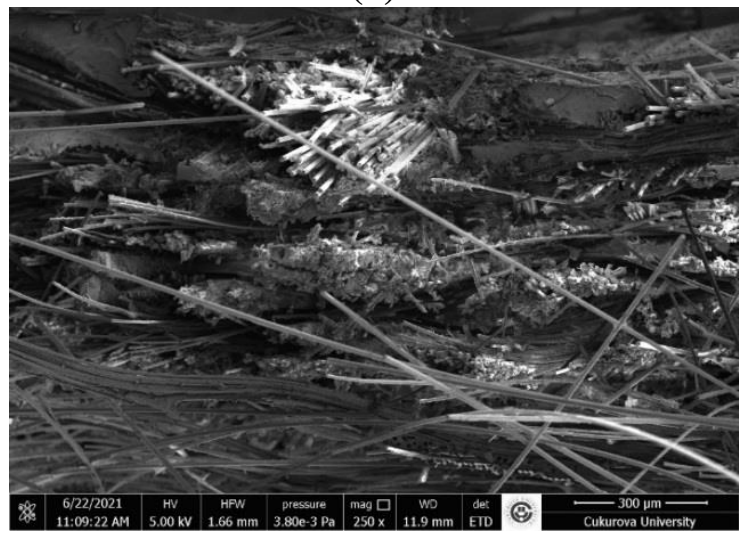

(c)

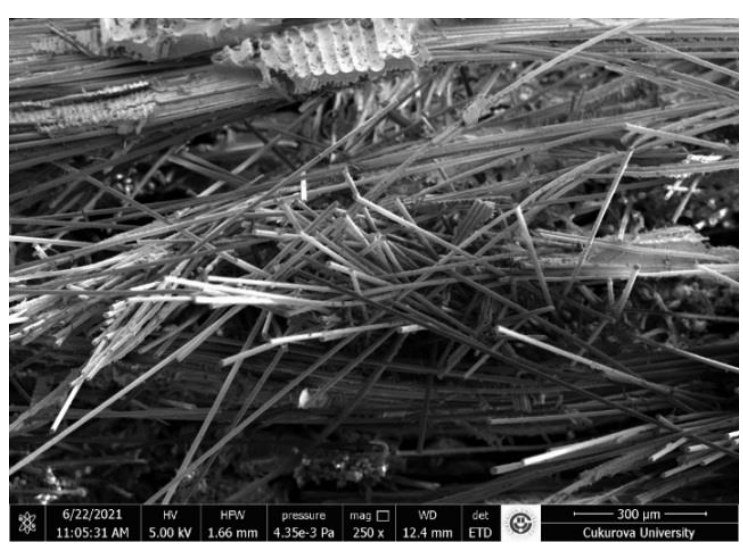

(b)

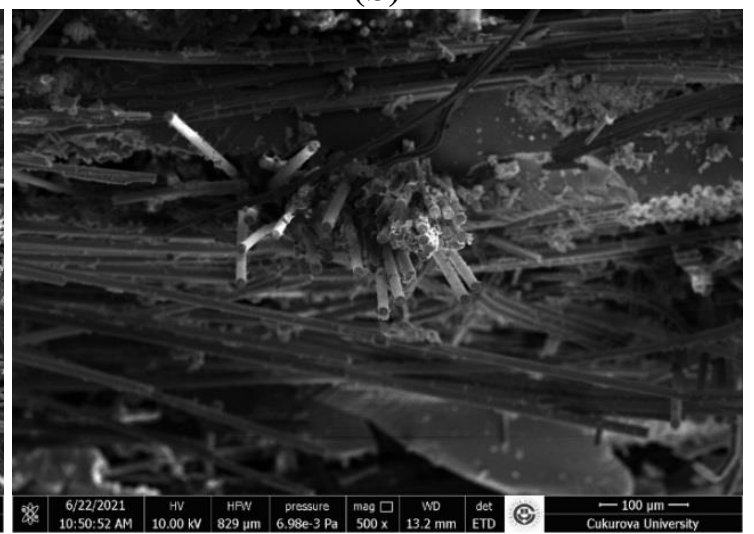

(d) 


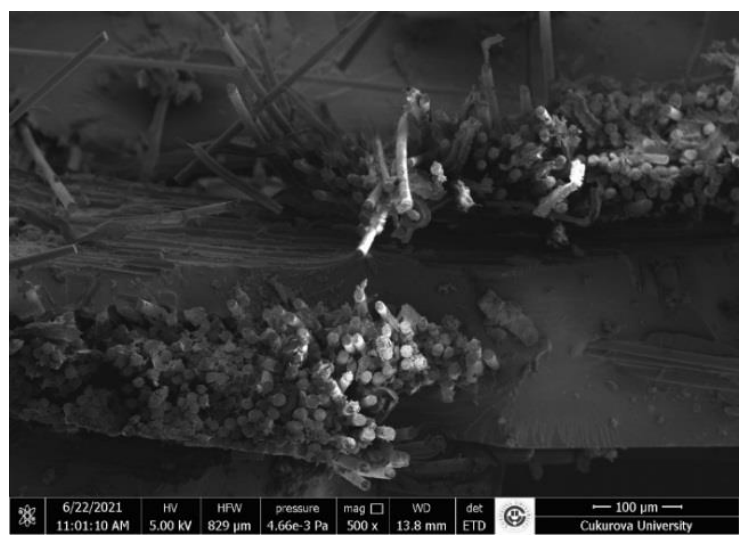

(e)

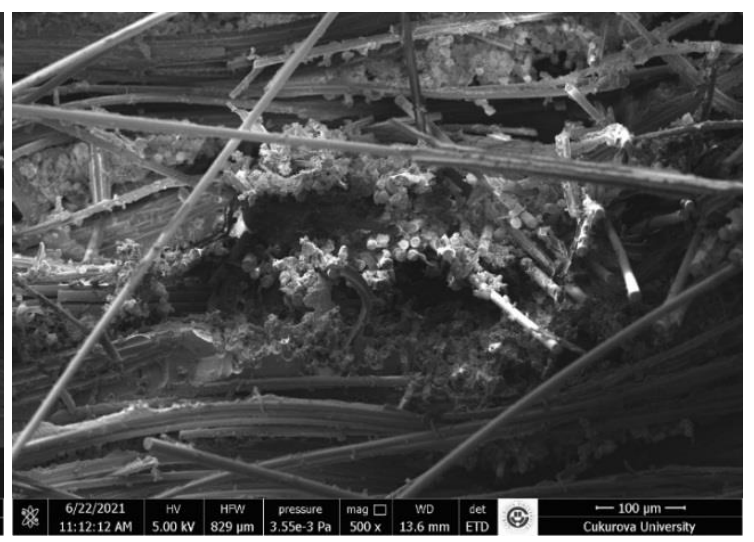

(f)

Figure 11. SEM images of a) JB Vinylester b) BG86 Vinylester c) BG100 Vinylester d) JB Epoxy e) BG86 Epoxy f) BG100 Epoxy

\section{CONCLUSION}

The effects of hybridization and usage of different matrix materials on basalt fiber fabric/jute fiber fabric, basalt fiber fabric/glass fiber fabric (86 $\left.\mathrm{gr} / \mathrm{m}^{2}\right)$, and basalt $/ \mathrm{glass}$ fiber $\left(100 \mathrm{gr} / \mathrm{m}^{2}\right)$ on tensile strength and hardness have been evaluated experimentally. In general, the performance of epoxy matrix reinforced composites was superior to the vinylester reinforced composites. The results obtained from tensile test, the tensile strength of the composite material stacked with Basalt/Glass fiber $\left(100 \mathrm{gr} / \mathrm{m}^{2}\right)$ array is higher than the composites produced with epoxy matrix materials stacked with Basalt/Jute fiber and Basalt/Glass fiber array $\left(86 \mathrm{gr} / \mathrm{m}^{2}\right)$. When compared to vinylester matrix composites BG100 with the epoxy matrix is also the highest value among the other sample specimens. Also, the use of epoxy matrix in the BG86 sample was $12.46 \%$ compared to the vinylester resin, and this rate was $11.17 \%$ in the BG100 sample, and it was viewed that the tensile strength increased with the use of the epoxy matrix. According to the results of the applied tests, it can be deduced that the stacking order affects the tensile strength properties of hybrid composites. The tensile strength of JB samples with vinylester matrix is higher than that of JB samples with epoxy matrix, which may be due to the sequence difference. In terms of microhardness, BG100 with epoxy matrix usage is
$39.9 \%$ higher than with vinylester matrix usage. This ratio is $64.05 \%$ for the BG86 sample and $80.78 \%$ for the JB sample. SEM shows delamination, fiber breakage, and stretching under tensile load with the use of epoxy and vinylester resin in the samples. Morphological structure examination is compatible with the mechanical results in the study. In hybrid composite materials, mechanical properties can be changed by changing the stacking order or by using different matrixes. In addition to this, more elaborated studies with different resin and material parameters are needed to take full benefit of the great strength and hardness features of the various hybrid configurations that can be formed with basalt, jute, and glass fibers.

\section{REFERENCES}

1. Monaldo, E., Nerilli, F.,Vairo, G., 2019. Basalt-Based Fiber-reinforced Materials and Structural Applications in Civil Engineering. Composite Structures, 214, 246-263.

2. Nayak, S.Y., Shenoy,S.,Hameed Sultan, M.T., Kini, C.R., Seth, A., Prabhu, S., Safri, S.N.A., 2021. Effect of CNT-Based Resin Modification on the Mechanical Properties of Polymer Composites. Frontiers in Materials, 7, 1-14.

3. Sfarra, S., Ibarra- Castanedo, C., Santulli, C., Paoletti, A., Paoletti, D., Sarasini, F., Bendada, A., Maldague, X., 2013. Falling Weight 
Impacted Glass and Basalt Fibre Woven Composites Inspected Using Non-destructive Techniques. Compos. Part B Eng. 45, 601-608.

4. Prasath, K.A., Krishnan, B.R., 2013. Mechanical Properties of Woven Fabric Basalt/Jute Fibre Reinforced Polymer Hybrid Composites. International Journal of Mechanical Engineering Robotics Research, 2(4), 279-290.

5. Andrew, J., Ramesh, C., 2015. Residual Strength and Damage Characterization of Unidirectional Glass-basalt Hybrid/Epoxy CAI Laminates. Arabian Journal for Science and Engineering, 40, 1695-1705.

6. Balaji, K.V., Shirvanimoghaddam, K., Rajan, G.S., Ellis, A.V., Naebe, M., 2020. Surface Treatment of Basalt Fiber for Use in Automotive Composites. Materials Today Chemistry, 17, 100334.

7. Abd El-Baky, M.A., Attia, M.A., Abdelhaleem, M.M., Hassan, M.A., 2020. Flax/basalt/E-glass Fibers Reinforced Epoxy Composites with Enhanced Mechanical Properties. Journal National Fibers, Ahead of Print, 1-15.

8. Bijlwan, P.P., Prasad, L., Sharma, A., 2021. Recent Advancement in the Fabrication and Characterization of Natural Fiber Reinforced Composite: A Review. Materials Today: Proceedings, 44, 1718-1722.

9. Fiore, V., Scalici, T., Di Bella, G., Valenza, A., 2015. A Review on Basalt Fibre and its Composite. Composites Part B: Engineering, 74, 74-94.

10. Mishra, R., Jamshaid, H., Militky, J., 2017. Basalt Nanoparticle Reinforced Hybrid Woven Composites: Mechanical and Thermomechanical Performance. Fibers Polymers. 18, 2433-2442.

11.Zareei, N., Geranmayeh, A., Eslami-Farsani, R., 2019. Interlaminar Shear Strength and Tensile Properties of Environmentally-friendly Fiber Metal Laminates Reinforced by Hybrid Basalt and Jute Fibers. Polymer Testing, 75, 205-212.

12. Tóth, L.F., Sukumaran, J., Szébenyi, G., Kalácska, A., Fauconnier, D., Nagarajan, R., De Baets, P., 2020. Large-scale Tribological Characterisation of Eco-friendly Basalt and Jute Fibre Reinforced Thermoset Composites.
Wear, 450-451, 203274.

13. Sapuan, S.M., Aulia, H.S., Ilyas, R.A., Atiqah, A., Dele-Afolabi, T.T., Nurazzi, M.N., Supian, A.B.M., Atikah, M.S.N., 2020. Mechanical Properties of Longitudinal Basalt/woven-glassfiber-reinforced Unsaturated Polyester-resin Hybrid Composites. Polymers (Basel), 12, 1-14.

14. Saleem, A., Medina, L., Skrifvars, M., Berglin, L., 2020. Hybrid Polymer Composites of Biobased Bast Fibers with Glass, Carbon and Basalt Fibers for Automotive Applications-A Review. Molecules, 25(21), 4933.

15. Petrucci, R., Santulli, C., Puglia, D., Nisini, E., Sarasini, F., Tirillò, J., Torre, L., Minak, G., Kenny, J.M., 2015. Impact and Post-impact Damage Characterisation of Hybrid Composite Laminates Based on Basalt Fibres in Combination with Flax, Hemp and Glass Fibres Manufactured by Vacuum Infusion. Composites Part B Engineering, 69, 507-515.

16. Sarasini, F., Tirillò, J., Valente, M., Valente, T., Cioffi, S., Iannace, S., Sorrentino, L., 2013. Effect of Basalt Fiber Hybridization on the Impact Behavior Under Low Impact Velocity of Glass/basalt Woven Fabric/epoxy Resin Composites. Composites Part A Applied Sciences Manufacturing, 47, 109-123.

17. Santosh Gangappa, G., Sripad Kulkarni, S., 2021. Experimentation and Validation of Basalt \& Jute Fiber Reinforced in Polymer Matrix Hybrid Composites. Materails Today Proceedings, 38, 2372-2379.

18. Jusoh, M.S.M., Yahya, M.Y., Hussein, N.I.S., 2016. The Effect of Fibre Layering Pattern in Resisting Bending Loads of Natural Fibrebased Hybrid Composite Materials. MATEC Web of Conferences, 39, 1-6.

19. Dhiman, P., Sharma, H., 2021. Effect of Walnut Shell Filler on Mechanical Properties of Jute-basalt Hybrid Epoxy Composites. Materials Today: Proceedings, 44, 4537-4541.

20. Kishore, M., Amrita, M., Kamesh, B., 2021. Tribological Properties of Basalt-jute Hybrid Composite with Graphene as Nanofiller. Materials Today: Proceedings, 43, 244-249.

21. Kishore, M., Amrita, M., Kamesh, B., 2021. Experimental Investigation of Milling on Basalt-jute Hybrid Composites with Graphene 
Effect of Various Matrix Materials on Mech. Prop. of Basalt/Jute/Glass fiber Reinf. Hybrid Comp.

as Nanofiller. Materials Today: Proceedings, 43, 726-730.

22. Fiore, V., Scalici, T., Sarasini, F., Tirilló, J., Calabrese, L., 2017. Salt-fog Spray Aging of Jute-basalt Reinforced Hybrid Structures: Flexural and Low Velocity Impact Response. Composites Part B Engineering, 116, 99-112.

23. Ma, G., Yan, L., Shen, W., Zhu, D., Huang, L., Kasal, B., 2018. Effects of Water, Alkali Solution and Temperature Ageing on Water Absorption, Morphology and Mechanical Properties of Natural FRP Composites: Plantbased Jute vs. Mineral-based Basalt. Composites Part B Engineering, 153, 398-412.

24. Raajeshkrishna, C.R., Chandramohan, P., Saravanan, D., 2019. Effect of Surface Treatment and Stacking Sequence on Mechanical Properties of Basalt/glass Epoxy Composites. Polymers and Polymer Composites, 27, 201-214.

25. Fiore, V., Scalici, T., Badagliacco, D., Enea, D., Alaimo, G., Valenza, A., 2017. Aging Resistance of Bio-epoxy Jute-basalt Hybrid Composites as Novel Multilayer Structures for Cladding. Composite Structures, 160 1319-1328.

26. Sánchez-Gálvez, V., Sancho, R., Gálvez, F., Cendón, D., Rey-de-Pedraza, V., 2020. High Speed Impact Performance of Basalt Fiber Reinforced Vinylester Composites at Room and Low Temperatures. International Journal of Lightweight Materials \& Manufacture, 3, 416-425.

27. Jusoh, M.S.B.M., Ahmad, H.A.B.I., Yahya, M.Y., 2017. Indentation and Low Velocity Impact Properties of Woven E-glass Hybridization with Basalt, Jute and Flax Toughened Epoxy Composites. $20173^{\text {rd }}$ International Conference on Power Generation Systems and Renewable Energy Technologies (PGSRET), 164-168.

28. Esnaola, A., Ulacia, I., Aretxabaleta, L., Aurrekoetxea, J., Gallego, I., 2015. Quasi-static Crush Energy Absorption Capability of Eglass/polyester and Hybrid E-glassbasalt/polyester Composite Structures. Material and Design, 76, 18-25.

29. ASTM D3039/D3039-M.2000. Standard Test Method for Tensile Properties of Polymer
Matrix Composite Material, www.astm.org.

30. Jawaid, M., Thariq, M., Saba, N., 2019. Structural Health Monitoring of Biocomposites, Fibre-reinforced Composites and Hybrid Composites. Woodhead Publishing Series, $1^{\text {st }}$ Edition, 246-256.

31. ASTM E92-17. 2017. Standard Test Methods for Vickers Hardness and Knoop Hardness of Metallic Materials. www.astm.org.

32. Colombo, C., Vergani, L., Burman, M., 2012. Static and Fatigue Characterisation of New Basalt Fibre Reinforced Composites. Composites Structures, 94(3), 1165-1174. 